\title{
Geographic and seasonal variability in feeding behaviour of a small herbivorous rodent
}

\author{
Paola L. Sassi • Carlos E. Borghi • Maria A. Dacar • \\ Francisco Bozinovic
}

Received: 17 September 2009 / Accepted: 4 June 2010/Published online: 10 November 2010

(C) Mammal Research Institute, Polish Academy of Sciences, Białowieża, Poland 2010

\begin{abstract}
Foraging strategies have traditionally been modelled as a result of food selection in response to one factor, as for instance resource availability, deterrent compounds or nutrients. Thus, a trade-off is assumed between plasticity (generalist strategy) and efficiency (specialist strategy). Nevertheless, several studies have demonstrated that animals cope behaviourally with food supply variation. For instance, desertdwelling rodents partially compensate for nutritional bottlenecks through diet selection. The aim of our study was
\end{abstract}

Communicated by: Joseph F. Merritt

P. L. Sassi $(\bowtie) \cdot$ M. A. Dacar

Biodiversity Research Group, Instituto Argentino de

Investigaciones de las Zonas Áridas, CCT-Mendoza, CONICET,

Av. Ruiz Leal s/n, CC 507,

5500 Mendoza, Argentina

e-mail: paola.sassi@gmail.com

P. L. Sassi

e-mail: psassi@mendoza-conicet.gob.ar

M. A. Dacar

e-mail: mdacar@mendoza-conicet.gob.ar

C. E. Borghi

Biological Interactions in Deserts (INTERBIODES),

Departamento de Biología y Museo de Ciencias Naturales,

Universidad Nacional de San Juan-CONICET,

San Juan, Argentina

e-mail: cborghi@unsj-cuim.edu.ar

C. E. Borghi

e-mail: carlos.borghi@gmail.com

F. Bozinovic

Center for Advanced Studies in Ecology and Biodiversity,

Departamento de Ecología,

Pontificia Universidad Católica de Chile,

P.O. Box 6513677, Santiago, Chile

e-mail: fbozinov@bio.puc.cl to test how foraging behaviour matches spatial and temporal variations in the trophic environment and how modelling hypotheses help us to understand the resultant foraging strategy. Our animal study model was the small cavy Microcavia australis, a widely distributed herbivorous rodent. Fieldwork was carried out in four places, in wet and dry seasons. We found significant differences in plant cover, plant diversity and niche breadth, and diet selection revealed a complex foraging strategy. M. australis shows a behavioural repertoire that exceeds single-criterion categories; therefore, we appeal to theoretical models that consider ecological and physiological perspectives. We classified the small cavy as a facultative specialist displaying a thoroughly opportunistic strategy based on the plasticity of the behavioural phenotype. We finally discuss the evolutionary relevance of our results and propose further investigation avenues.

Keywords Behavioural plasticity. Diet selection . Environmental heterogeneity $\cdot$ Microcavia australis . Nutritional trade-offs

\section{Introduction}

According to classic niche theory, foraging strategies vary depending on the degree of dietary specialization (Colwell and Futuyma 1971; Sánchez-Gonzáles et al. 2001). Dietary specialists have been defined as those species that consume items in a greater proportion than found in the environment (Feinsinger et al. 1981). There is also general agreement that a specialist consumes more than $50 \%$ of one particular item (Giannoni et al. 2005). Recent studies have defined a specialist herbivore as one that displays unique behavioural, physiological or morphological adaptations to consume difficult food (Shipley et al. 2009). Difficult food items are 
those that are avoided by most herbivores because of chemical or physical characteristics that lower their quality per unit of time invested to obtain them (Robinson and Wilson 1998).

Foraging theory attempts to define general rules about what animals feed on. The most frequently used model for diet selection is the contingency model which assumes that an animal maximizes the rate of ingestion of energy in food, or another currency. For instance, the classical optimal foraging theory (OFT) considers resource availability as the most important determinant and predicts that herbivores should maximize the amount of energy obtained per unit of time if everything else is equal (MacArthur and Pianka 1966). On the other hand, the nutrient balance hypothesis states that, optimally, the selected diet should necessarily provide certain nutrients (Rapport 1980). Finally, the toxin-avoidance hypothesis proposes that animals will select their food so as to minimize ingestion of plant secondary compounds (PSC; Freeland and Janzen 1974). Dicot plants from arid environments are generally slow developing, which favours production of constitutive immobile chemical defences, such as lignin, cellulose and resins in high concentrations with low renewal rates (Coley et al. 1985). These common compounds (Rhoades 1977; Meyer and Karasov 1991) impose costs on animals consuming them (Foley and McArthur 1994; Mangione et al. 2004).

McArthur et al. (1991) broadly categorized herbivores into different strategies based on their ability to deal with PSC. This classification includes generalists that eat monocots on one side and specialists on a single item exposed to high amounts of a single type of PSC on the other side. Between these extremes, the authors propose intermediate strategies including consumption of plants in diverse proportions, therefore exposing herbivores to intermediate or low levels of different types of PSC (Mangione and Bozinovic 2003). Nevertheless, this classification, as the classic model by MacArthur and Pianka (1966), establishes that organisms within a species cannot efficiently handle shifting types of food. Thus, a trade-off is assumed between dietary plasticity and foraging efficiency. Some recent studies consider the evolutionary mechanisms underlying foraging strategies, such as stasis or phenotypic plasticity (Sherry 1990; Shipley et al. 2009). Particularly for mammals, Shipley et al. (2009) propose a specialization key to place herbivores along a specialist-generalist continuum by considering the fundamental niche, available, acceptable and realized diets and the difficulty of plants consumed (Table 1). Resulting categories are generalist and specialist (based on diet diversity), modified by the terms facultative and obligatory (based on the flexibility to use difficult foods). The authors also state that their model captures the dynamic aspects of dietary selection (i.e. spatial and temporal scales), which presents an interesting problem to be tested in the field.
Colonization and survival of small mammals in xeric habitats is in part accomplished through behavioural strategies. Water and nutritional balance are significant challenges, particularly for desert-dwelling herbivorous rodents (Bozinovic 1993; Diaz and Ojeda 1999; Kenagy et al. 1999; Bozinovic and Gallardo 2006), which face comparatively low-quality food during nutritional bottlenecks (Bozinovic 1995, 1997; Bozinovic et al. 1997; Torres-Contreras and Bozinovic 1997; Sassi et al. 2007).

The aim of our study was to test how foraging behaviour matches spatial and temporal variation in food supply and to discuss the theoretical criteria used to classify species according to their foraging strategies. The model animal was Microcavia australis, a hystricognath rodent of ca. 250-300 g, which occurs throughout a wide range of arid and semiarid environments in the southern part of South America (Redford and Eisenberg 1992). This cavy is a strict herbivore and previous studies have described it as a highly flexible species in response to the seasonality of resource availability (Campos et al. 2001). However, its dietary diversity has not been assessed over a large spatial scale, which could reveal a variation in the pathways for obtaining adequate energy and nutrients.

We hypothesized that the foraging behaviour of $M$. australis would fit with seasonal and spatial variations in abundance and diversity of trophic resources by means of a complex strategy.

\section{Material and methods}

\section{Study area}

Fieldwork was carried out during 2004 and 2005 at four sites in Argentina: (1) Private Reserve of Villavicencio, (2) MaB Reserve of Ñacuñán, (3) Matagusanos and (4) El Leoncito National Park. These localities lie within the distribution range of $M$. australis (Redford and Eisenberg 1992), are each separated by at least $200 \mathrm{~km}$ and differ in temperature and rainfall regimes.

The Private Reserve of Villavicencio presents different vegetation belts along an altitudinal gradient where Monte and Cardonal phytogeographic regions are represented (Dalmasso et al. 1999). The study area is in a valley $\left(32^{\circ} 26.6^{\prime} \mathrm{S}, 69^{\circ}\right.$ $1.75^{\prime} \mathrm{W}$, altitude $=2,187 \mathrm{~m}$ ) at the ecotone between these regions. Dominant vegetation consists of shrub species, such as Larrea nitida, Schinus fasciculatus and Zucagnia punctata. The herb stratum includes Descurainia argentina and Phacelia sp. among others. The weather is semiarid; rainfall occurs mainly in summer whereas snow is the predominant winter precipitation. Mean annual rainfall is $324.5 \mathrm{~mm}$. Mean temperatures are $17^{\circ} \mathrm{C}$ in summer and $5^{\circ} \mathrm{C}$ in winter (Ambrosetti et al. 1986). 
Table 1 Specialization key extracted from Shipley et al. (2009)

\begin{tabular}{|c|c|c|c|c|}
\hline Herbivore type & Fundamental niche & Available diet & Realized niche & Realized diet \\
\hline Obligate specialist & $\begin{array}{l}\text { Very broad along } \\
\text { some axes, narrow }{ }^{\mathrm{b}} \\
\text { along most }\end{array}$ & Difficult; often restricted & Very narrow; difficult & Restricted; difficult \\
\hline Facultative specialist ${ }^{\mathrm{a}}$ & $\begin{array}{l}\text { Very broad along some } \\
\text { axes, broad along } \\
\text { others }\end{array}$ & $\begin{array}{l}\text { Difficult; restricted, } \\
\text { moderately difficult; } \\
\text { diverse }\end{array}$ & $\begin{array}{l}\text { Narrow; difficult or } \\
\text { Very broad; moderately } \\
\text { difficult }\end{array}$ & $\begin{array}{l}\text { Restricted; difficult or } \\
\text { Diverse; difficult to } \\
\text { moderately easy }\end{array}$ \\
\hline Facultative generalist $\mathrm{t}^{\mathrm{a}}$ & Broad along most axes & $\begin{array}{l}\text { Moderately easy; diverse } \\
\text { or an easy component } \\
\text { is abundant }\end{array}$ & $\begin{array}{l}\text { Broad; moderately easy } \\
\text { or Narrow; easy }\end{array}$ & $\begin{array}{l}\text { Diverse; moderately } \\
\text { difficult or Easy plants } \\
\text { restricted; easy }\end{array}$ \\
\hline Obligate generalist & $\begin{array}{l}\text { Moderately narrow } \\
\text { along most axes }\end{array}$ & Easy; diverse & Moderately narrow; easy & Moderately diverse; easy \\
\hline
\end{tabular}

${ }^{\text {a }}$ Realized diet is dependent upon available diet and may shift between seasons or habitats

b Some boundaries on the "easy" side of the niche may be maintained by behavioural mechanisms which may sometimes be overcome

The MaB Reserve of Ñacuñán belongs to the Monte desert phytogeographic province (Ojeda et al. 1998). The study area $\left(34^{\circ} 0.2^{\prime} \mathrm{S}, 67^{\circ} 58^{\prime} \mathrm{W}\right.$, altitude $\left.=540 \mathrm{~m}\right)$ is located in the mesquite forest, the preferred habitat of $M$. australis (Campos 1997). This plant community is constituted by three welldefined strata: (1) the tree stratum dominated by Prosopis flexuosa, (2) the shrub stratum with Larrea divaricata, Atriplex lampa, Lycium chilense etc. and (3) a diverse herb stratum. The weather is arid-semiarid, rainfall concentrates in summer and its annual mean is $340.3 \mathrm{~mm}$. Mean temperatures are $22.1^{\circ} \mathrm{C}$ in summer and $8.7^{\circ} \mathrm{C}$ in winter.

Matagusanos is located in a geographic depression surrounded by hills, at the arid extreme of the Monte desert (Poblete and Minetti 1989). Consequently, the landscape presents very low plant cover with patches of xerophytic vegetation associated with subterranean water courses. $M$. australis establishes its colonies around mesquite trees $(P$. flexuosa $)$ in these patches. On the study site $\left(31^{\circ} 20^{\prime} \mathrm{S}, 68^{\circ} 30^{\prime}\right.$ $\mathrm{W}$, altitude $=598 \mathrm{~m}$ ), vegetation consists of a tree stratum, a shrub stratum with Larrea cuneifolia, Bulnesia retama etc. and a poor herb stratum. The climate is hyperarid; mean annual rainfall is $70 \mathrm{~mm}$ and occurs during summer. Mean temperatures are $26.6^{\circ} \mathrm{C}$ in summer and $7.4^{\circ} \mathrm{C}$ in winter.

Finally, El Leoncito National Park is located in the southwest of San Juan province (Haene 1996) and comprises different phytogeographic regions (Márquez 1999). For this study, we selected a site in Monte $\left(31^{\circ} 47^{\prime}\right.$ $\mathrm{S}, 69^{\circ} 17^{\prime} \mathrm{W}$, altitude $=2,500 \mathrm{~m}$ ). Soils are sandy and plant cover is scarce (Bracco and Contreras 2000). There is a shrub stratum mainly composed of $L$. nitida, a sparse herbaceous stratum and isolated patches of graminoids (Márquez and Dalmasso 2003). The weather is arid and temperate, and average annual precipitation is $90 \mathrm{~mm}$ : Most of it occurs in the form of snow $(75 \mathrm{~mm})$ and summer rains $(10 \mathrm{~mm})$. Mean temperatures are $21^{\circ} \mathrm{C}$ in summer and $7{ }^{\circ} \mathrm{C}$ in winter.
Field and laboratory work

We performed vegetation sampling at each locality during both wet and dry seasons (winter and summer, respectively). Firstly, the sampling unit area was determined for each site by the minimal area method (Matteucci and Colma 1982). This method consists in recording species richness in exponentially increasing sampling areas, until no new species are recorded. At each site and season, we randomly set six strip transects within the areas $M$. australis inhabits. Along each transect, we placed 13 sample quadrats, interspersed with equal-sized quadrats. At each quadrat, we assessed the following variables: (1) total plant cover, (2) percent cover per plant species and (3) number of individuals per plant species.

Simultaneously, we sampled fresh faeces from six individuals trapped at each locality and season for diet characterization. Faeces were taken to the laboratory, dried at $60^{\circ} \mathrm{C}$ and macerated in a $17.5 \% \mathrm{NaHCO}_{3}$ solution (sodium bicarbonate; Dacar and Giannoni 2001). For each sample, a slide was prepared and 50 fields systematically examined under a microscope at $\times 40$. Histological features of leaf epidermis, seed coats, fruits and arthropod body parts were used to identify food items on slides. All items were identified by comparison with material from the reference collection of our laboratory. Presence of all food items was recorded and their relative percentage of occurrence was determined across all fields of a sample slide (Holechek and Gross 1982).

\section{Statistical analysis}

We carried out comparisons of plant cover data among sites and seasons as an estimate of resource availability. For this purpose, we performed a nested ANOVA with plant cover as dependent variable, site and seasons as fixed factors and 
transects within sites as a random factor in order to control for dependence among the data. Data on percent plant cover were transformed to arcsin ( $\checkmark$ proportion) in order to meet ANOVA requirements. We also performed a Tukey test for post hoc comparisons.

Using data on cover per species, we calculated the Shannon-Wiener index to estimate resource supply diversity for each site, season and transect by bootstrapping and performed a nested ANOVA with diversity index as dependent variable, site and seasons as fixed factors and transects within sites as a random factor in order to control for dependence among the data.

Data on the proportion of occurrence of each plant species in the food supply plus data on species proportion in diet were used to calculate the proportional similarity index (PSI; Feinsinger et al. 1981). PSI measures the intersection between distribution of available resources and distribution of resource use. It varies between 0 and 1 and increases with similarity between both distributions (plant cover and diet). In sum, a higher PSI value means the individual is eating food in a similar proportion to that found in the environment, and a lower PSI value indicates the converse (i.e. high selectivity). Proportional similarity values $(n=6)$ from each site and season were used to perform factorial ANOVA, with site and season as fixed factors and PSI as the dependent variable. We also performed Tukey tests for post hoc comparisons.

To investigate response patterns of niche breadth to variation in trophic availability, multiple regression analyses of plant cover and plant diversity on PSI were conducted.

Finally, diet selection was assessed by determining selectivity or avoidance of plant species by $M$. australis. For this purpose, proportions of each plant species in the food supply and in the diet were compared applying Kolmogorov-Smirnov non-parametric tests. Selectivity was assumed when the proportion of an item was significantly higher in the diet than in the food supply, and avoidance was assumed when the proportion of an item was significantly higher in the food supply than in the diet.

\section{Results}

Sites differed in plant cover $(F=23.46, d f=3, p=0.0001)$, as expected from information on precipitation and temperature. Particularly, there were significant differences among all sites except between Nacunán and Villavicencio (Tukey's test $p<$ $0.05)$. Plant cover was significantly higher in the wet than in the dry season $(F=18.76, d f=1, p=0.0017)$, and there was no significant interaction between site and season (Table 2). Sites showed significant differences in plant species diversity ( $F=64.96, d f=3, p=0.0001)$, with higher values being recorded for Villavicencio and Ñacuñán and lower values for Matagusanos and El Leoncito. There were no significant differences between seasons (Table 2).

The proportional similarity index resulted in significant differences among sites $(F=49.73, d f=3, p=0.0001)$, there was no significant effect of season $(F=0.004, d f=1, p=$ $0.94)$ and interaction between site and season was significant $(F=25.90, d f=3, p=0.0001)$ probably due to converse results among sites that masked the effect of season. Tukey tests detected significant seasonal variations within sites: At Villavicencio, PSI increased in the dry season $(p=0.0001)$, whereas at Ñacuñán, PSI showed a marginally significant decrease in the dry season $(p=0.0502)$.

Multiple regressions of niche breadth yielded mixed results: Plant cover effect was not significant, while plant diversity was positively and significantly associated to the PSI $\left(R^{2}=0.33, p=0.03\right)$.

Food selection and avoidance made by $M$. australis when exposed to different resource supply situations (site and season) are plotted in Fig. 1.

At Villavicencio (Fig. 1a), M. australis selected several species from a relatively rich choice (25 species) in different proportions. The seasonal contrast here is due to stronger selection and avoidance in the wet season, with differences between diet and supply being greater than in the dry season (Table 2). Nevertheless, no species was found to make up more than $40 \%$ of the diet. At Nacuñán (Fig. 1b), M. australis showed strong selection and avoidance mainly of two species (P. flexuosa and $L$. divaricata, respectively), although supply richness was moderately high in both seasons (18 species). At Matagusanos (Fig. 1c), where P. flexuosa occurred as well, M. australis strongly selected it during both seasons. Although richness was lower than in the former localities (ten species), the foraging pattern was analogous to that at Nacuñán with mesquite and L. cuneifolia. At El Leoncito (Fig. 1d), the trophic environment was relatively stable but poor (four to seven species in the supply). The diet consisted predominantly of $L$. nitida and was very similar to the frequency of occurrence of items, although $M$. australis used a slightly more selective diet in winter.

\section{Discussion}

Spatial heterogeneity and intra-specific variation

Trophic relations of animals have impact on their energy balance and, consequently, on their fitness (Karasov 1986). Moreover, they influence population dynamics and community structure and are one of the forces that shape and promote adaptive radiation at the evolutionary time scale (Hughes 1993).

Our study sites exhibited differences in plant cover and plant diversity, resulting in a gradient of resource availability. 
Table 2 Differences among sites and seasons regarding plant cover, plant diversity and proportional similarity index

\begin{tabular}{|c|c|c|c|c|c|c|c|c|}
\hline \multirow{2}{*}{$\begin{array}{l}\text { Site } \\
\text { Season }\end{array}$} & \multicolumn{2}{|l|}{ Villavicencio } & \multicolumn{2}{|l|}{ Ñacuñán } & \multicolumn{2}{|c|}{ Matagusanos } & \multicolumn{2}{|l|}{ El Leoncito } \\
\hline & Wet & Dry & Wet & Dry & Wet & Dry & Wet & Dry \\
\hline Plant cover & $0.55 \pm 0.03$ & $0.44 \pm 0.02$ & $0.59 \pm 0.04$ & $0.51 \pm 0.03$ & $0.33 \pm 0.03$ & $0.23 \pm 0.03$ & $0.26 \pm 0.04$ & $0.16 \pm 0.02$ \\
\hline Effects $(p)$ & \multicolumn{3}{|l|}{ Site $=0.0001$} & \multicolumn{2}{|c|}{ Season $=0.0001$} & \multicolumn{3}{|c|}{ Site $\times$ Season $=0.926$} \\
\hline Plant diversity & $1.46 \pm 0.14$ & $1.85 \pm 0.13$ & $1.48 \pm 0.07$ & $1.71 \pm 0.04$ & $1.03 \pm 0.12$ & $0.71 \pm 0.13$ & $0.25 \pm 0.13$ & $0.26 \pm 0.09$ \\
\hline Effects $(p)$ & \multicolumn{3}{|l|}{ Site $=0.0001$} & \multicolumn{2}{|c|}{ Season $=0.363$} & \multicolumn{3}{|c|}{ Site $\times$ Season $=0.027$} \\
\hline Proportional similarity & $0.17 \pm 0.05$ & $0.56 \pm 0.03$ & $0.46 \pm 0.01$ & $0.31 \pm 0.02$ & $0.51 \pm 0.03$ & $0.39 \pm 0.01$ & $0.81 \pm 0.02$ & $0.68 \pm 0.05$ \\
\hline Effects $(p)$ & \multicolumn{3}{|l|}{ Site $=0.0001$} & \multicolumn{2}{|c|}{ Season $=0.948$} & \multicolumn{3}{|c|}{ Site $\times$ Season $=0.0001$} \\
\hline
\end{tabular}

Values are presented as mean \pm standard error, plus statistical effects of each factor and their interaction

Changes in diet selection among populations of $M$. australis matched this spatial heterogeneity. In fact, trophic niche breadth increased as a function of diversity of the food supply across populations, as regressions reveal. These data support predictions from the OFT: the greater the availability of resources, the greater the specialization of the foraging strategy (MacArthur and Pianka 1966; Schoener 1971; Feinsinger et al. 1981).

Implications of foraging behaviour at the population scale

The different sites are characterized by some dominant plant species, and the chemical identity of these plants could also play a role in determining the foraging behaviour of each population. The diet of $M$. australis consists mostly of dicots, and consequently, it contains more lignin (a digestibility reducer; Robbins 1993) than the diets of other sympatric rodents which are grasseaters, such as Galea musteloides, Lagidium viscacia and Dolichotis patagona (Campos et al. 2001). Dicots are highly variable in their content of fibre and PSC, for instance, D. argentina and Lecanophora ecristata have small quantities of fibre and PSC, which makes them palatable, whereas Larrea sp., Capparis sp. and Schinus sp. have large amount of deterrent chemicals like resins, tannins and alkaloids. In spite of all this, M. australis seems to choose resources that are stable over time (Campos et al. 2001, this study), which indicates that its diet selection is constrained by the nutritional benefits and accessibility of plants instead of by restrictive factors like fibre and PSC. This is consistent with the criterion of maximization of quality and energy yield of ingested food. For example, at Nacuñán and Matagusanos, diets were dominated by $P$. flexuosa, a nitrogen-rich legume, and therefore highly preferred by herbivores (Bozinovic 1997; Owen-Smith 1993; Robbins 1993). The nutrient balance hypothesis explains diet selection at Nacuñán and Matagusanos, where the cavy selects a non-abundant but highly nutritive resource (Campos 1997). The difference between populations at these sites lies in the availability of alternative resources to $P$. flexuosa. Therefore, $M$. australis includes more species in its diet, particularly annual herbs and grasses, and displays higher selectivity at Ñacuñan than at Matagusanos.

Both the highest diversity of trophic items and the highest diet selectivity occur at Villavicencio, supporting OFT. L. nitida, well-known to contain high levels of phenolic resins (Rhoades 1977), is not avoided as would be predicted according to the toxin-avoidance hypothesis. Palatable species, like D. argentina, L. ecristata and $L$. chilense, appear in a higher proportion in the diet than in the habitat, particularly in summer. Nevertheless, no item exceeded $40 \%$ of occurrence in the diet throughout the year which, according to the abundance criterion (Giannoni et al. 2005) and contrary to Feinsinger et al. (1981), would suggest a generalist diet.

El Leoncito population faces the lowest diversity of food supply, $90 \%$ of which is made up of L. nitida, in both seasons. Other plants are Schinus molle, also known by its high levels of PSC (Salem et al. 2006), and Cyperaceae with high fibre content (around 70\%; Santos et al. 2002). Alternatively, palatable Lycium chanar and D. argentina are scarce. This scenario is extremely unfavourable from the nutritional viewpoint. M. australis acts as a generalist, according to Feinsinger et al. (1981), as shown by the strong similarity between its diet and the food supply (relatively high PSI). PSI gives an ecological estimate of the degree of behavioural selectivity in the diet, and in this sense, El Leoncito population seems to select its diet as a time minimizer, according to the OFT. Nevertheless, the great abundance of certain food items indicates that the foraging strategy adopted would be a specialist strategy. As reported above for the Villavicencio population, in this case, both criteria lead to contradictory conclusions as well.

In fact, the relative amount of L. nitida in the El Leoncito diet (75-85\%) implies a specific foraging strategy as viewed from a physiological perspective. It has been demonstrated that the phenolic resin of creosotebush 
Fig. 1 Comparison of the proportions of trophic items in the food supply and the diet for each site and season: a Villavicencio, b Nacunán, c Matagusanos and d El Leoncito. Curves for both distributions show differences between items in diet and supply. Asterisks indicate significant differences between each species' proportion. $x$-axis shows the species list and $y$-axis shows the frequency standardized at 0.95 to make the figures comparable
A
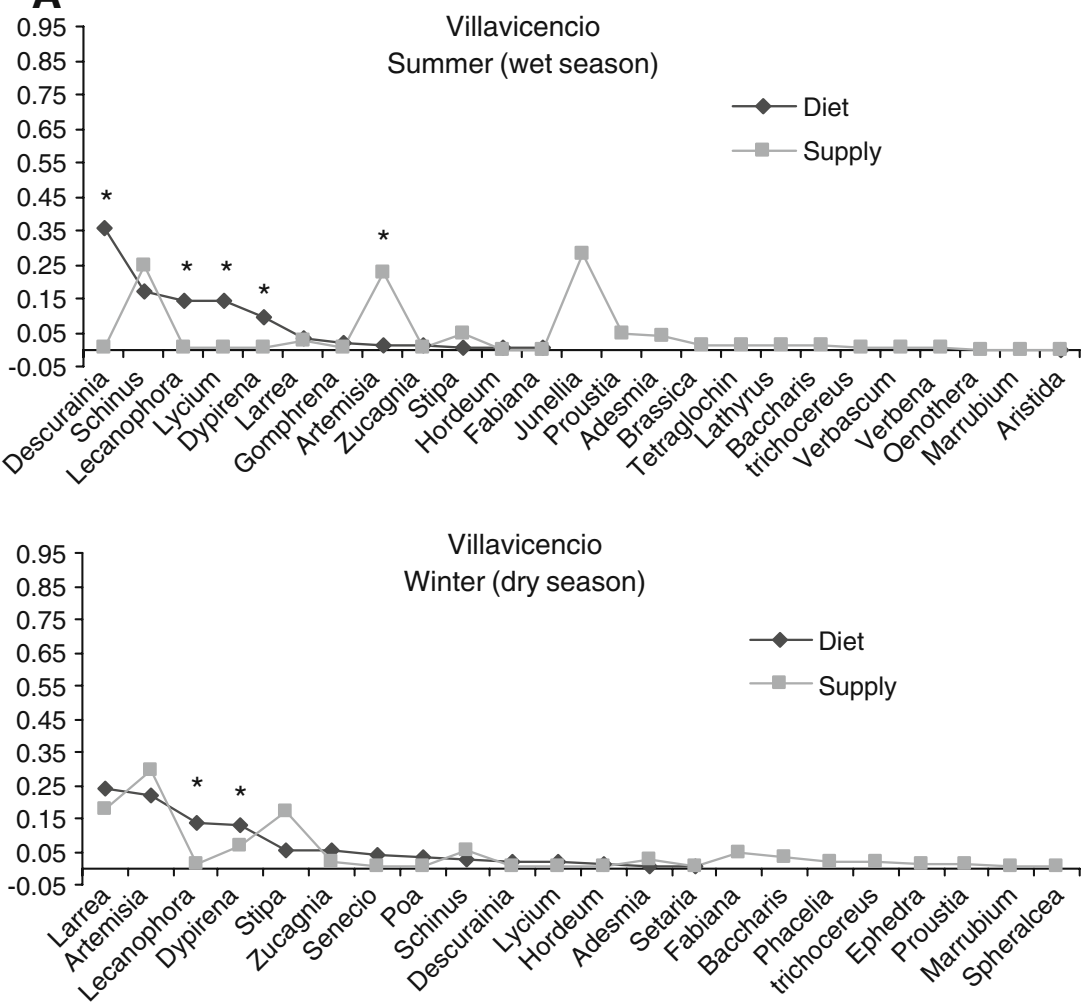

B

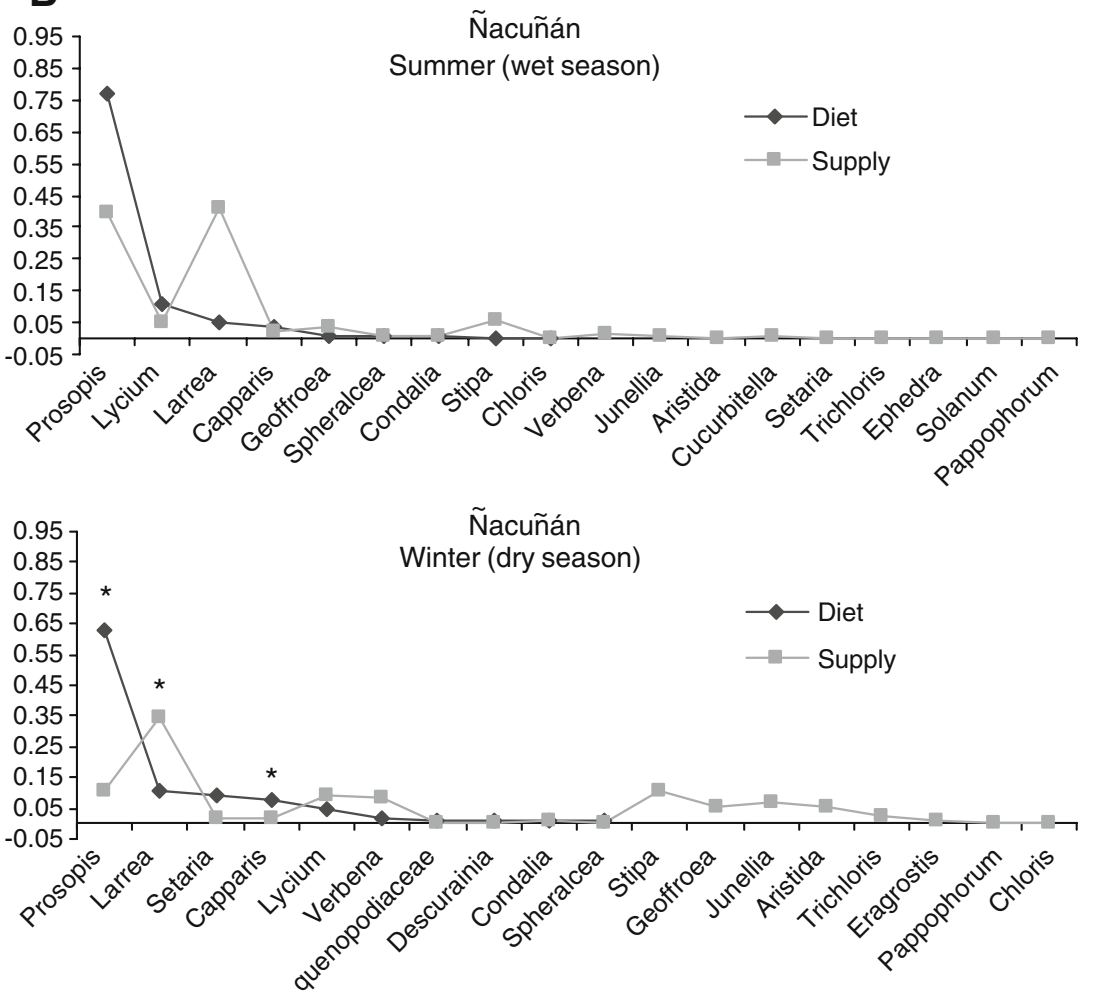


Fig. 1 (continued)
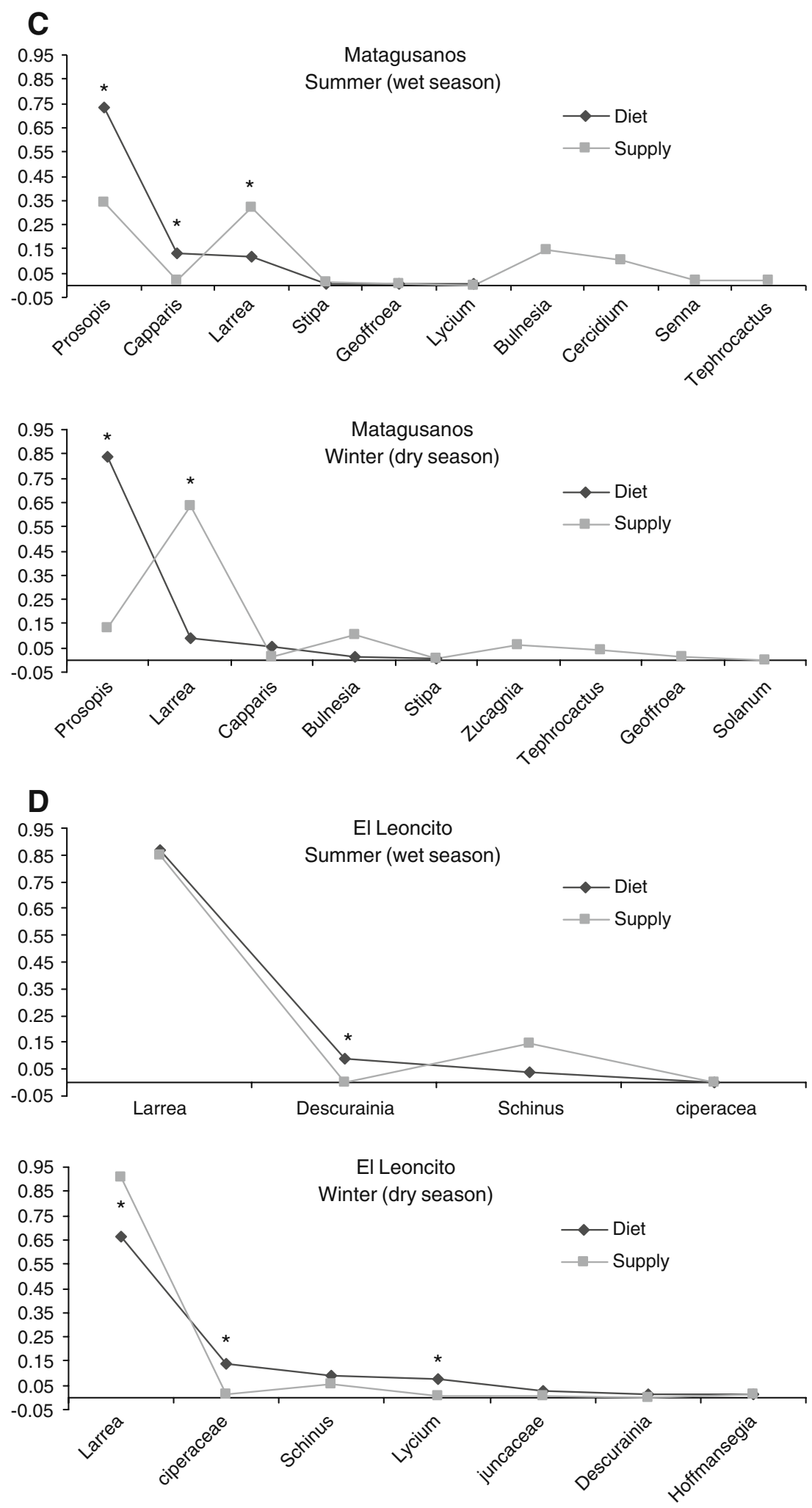

negatively affects reproduction, energy budget and water balance (Dearing et al. 2001; Mangione et al. 2004), all crucial to a desert-dwelling rodent. Undoubtedly, all these could impact the evolutionary ecology of M. australis, as suggested for Neotoma lepida by Mangione et al. (2000). Therefore, the question arises as to which criterion is appropriate to model the response of the small cavy to variations in its trophic environment. 
Potential of models in data interpretation

Relative to the scenario proposed by McArthur et al. (1991), M. australis populations studied herein can be positioned along a gradient of dicot-eaters, starting with specialists in a diet high in PSC (El Leoncito) and switching to a generalist diet on several plant species with low levels of different PSC (i.e. Villavicencio), whereas the populations at Matagusanos and Ñacuñán would be intermediate along the generalist-specialist gradient. All these exceed the scope of criteria used to classify feeding strategies, since oligophagy or polyphagy seems to occur within both broad and narrow trophic niches of $M$. australis. In consequence, the response to the above question is that none of the cited traditional approaches fully explains all the strategies displayed by $M$. australis. This is probably because phenotypic plasticity underlies the species response strategy to temporal and spatial dynamics.

The model by Shipley et al. (2009) proposes among others a category called 'facultative specialist' that includes different tactics (monophagy/polyphagy) and degrees of diet difficulty (Table 1), which appears appropriate to explain our data. The high proportion of only a few plant species in the diet of $M$. australis at certain sites and seasons would rest on particular characteristics. In fact, dietary specialization is defined by Shipley et al. (2009) as a complex process shaped by genes, physiology and behaviour. Therefore, this apparent versatility in trophic niche exploitation should have an impact at the evolutionary level (Hughes 1993).

We conclude that $M$. australis is certainly a facultative specialist on dicots with a broad fundamental trophic niche, as well as short-term, local, mosaic and apparent specializations, depending on the scale. The result is a thoroughly opportunistic strategy, based on the plasticity of the behavioural phenotype, what Sherry (1990) calls an evolutionary generalist, and our results strongly support this hypothesis. Further studies are necessary to dissect the mechanisms that explain $M$. australis plasticity and its relevance to ecological success. Future investigations should also gather information to assess divergence among populations in the ability to deal with different local selective pressures from the nutritional environment, in order to know, for instance, if there are different active detoxification pathways in each population, or a general mechanism adequate to detoxify all PSMs present in the plants they eat.

Acknowledgements This work was funded by grants from Consejo Nacional de Investigaciones Científicas y Técnicas and Agencia Nacional de Promoción Cientifica y Técnica. We thank A. Sandobal from El Leoncito National Park; guards from Villavicencio Reserve, Museo de Cs. Naturales de San Juan; A. Srur, P. Taraborelli and S. Velez who helped us with the field work; A. Dalmasso who helped us with the plant species determination; A. Srur who made valuable suggestions on statistics; C. Campos who made valuable suggestions on an early draft of the manuscript and provided very useful bibliographic material for our work and Nelly Horak who helped us with the English version.

\section{References}

Ambrosetti J, Del Vitto LA, Roig F (1986) La Vegetación del paso de Uspallata, provincia de Mendoza, Argentina. Ber Geobotanisches Inst ETH Stift Rübel Zürich 91:141-180

Bozinovic F (1993) Nutritional ecophysiology of the Andean mouse Abrothrix andinus: energy requirements, food quality and turnover time. Comp Biochem Physiol A 104:601-604

Bozinovic F (1995) Nutritional energetics and digestive responses of an herbivorous rodent (Octodon degus) to different levels of dietary fiber. J Mammal 76:627-637

Bozinovic F (1997) Diet selection in rodents: an experimental test of the effect of dietary fiber and tannins on feeding behavior. Rev Chil Hist Nat 70:67-71

Bozinovic F, Gallardo P (2006) The water economy of South American desert rodents: from integrative to molecular physiological ecology. Comp Biochem Phys C 142:163-172

Bozinovic F, Novoa F, Nespolo RF (1997) Effect of dietary composition on food selection and assimilation in the leaf-eared mouse (Phyllotis darwini) inhabiting central Chile. Rev Chil Hist Nat 70:289-295

Bracco A, Contreras VH (2000) Caracterización Geológica. In: Relevamiento de los recursos Naturales de la Reserva Estricta El Leoncito. Secciones de Geología y Biología, Instituto y Museo de Cs. Naturales-UNSJ, San Juan, pp 3-11

Campos CM (1997) Utilización de los recursos alimentarios por mamíferos medianos y pequeños del desierto del Monte. Ph.D. thesis dissertation, Universidad Nacional de Córdoba, Argentina

Campos CM, Ojeda R, Monge S, Dacar MA (2001) Utilization of food resources by small and medium-sized mammals in the Monte Desert biome, Argentina. Austral Ecol 26:142-149

Coley PD, Bryant JP, Chapin FS (1985) Resource availability and plant antiherbivore defense. Science 230:895-899

Colwell RK, Futuyma DJ (1971) On the measurement of niche breadth and overlap. Ecology 52:567-576

Dacar MA, Giannoni SM (2001) A simple method for preparing reference slides of seed. J Range Manage 54:191-193

Dalmasso A, Martinez Carretero E, Videla F, Puig S, Candia R (1999) Reserva Natural Villavicencio (Mendoza, Argentina). Plan Manejo Multequina 8:11-50

Dearing MD, Mangione AM, Karasov WH (2001) Plant secondary compounds as diuretics: an overlooked consequence. Am Zool 41:890-901

Diaz GB, Ojeda R (1999) Kidney structure and allometry of Argentine desert rodents. J Arid Environ 41:453-461

Feinsinger P, Spears EE, Poole RW (1981) A simple measure of niche breadth. Ecology 62:27-32

Foley WJ, McArthur C (1994) The effects and costs of allelochemicals for mammalian herbivores: an ecological perspective. In: Chivers D, Langer P (eds) The digestive system in mammals: food, form and function. Cambridge University Press, Cambridge, pp 370-391

Freeland WJ, Janzen DH (1974) Strategies in herbivory by mammals: the role of plant secondary compounds. Am Nat 108:269-289

Giannoni SM, Borghi CE, Dacar MA, Campos CM (2005) Main food categories in diets of sigmodontine rodents in the Monte (Argentina). Mastozoología Neotrop 12:181-187

Haene E (1996) Antecedentes de la Reserva Natural Estricta El Leoncito. Enero 1994-Abril 1996. Departamento Conservación de 
Áreas Naturales Protegidas de la región Centro, Administración de Parques Nacionales, Buenos Aires

Holechek JL, Gross BD (1982) Evaluation of different calculation procedures for microhistological analysis. J Range Manage $35: 721-723$

Hughes RN (1993) Diet selection: an interdisciplinary approach to foraging behavior. Blackwell, Oxford

Karasov WH (1986) Energetics, physiology and vertebrate ecology. Trends Ecol Evol 1:101-104

Kenagy GJ, Veloso C, Bozinovic F (1999) Daily rhythms of food intake and feces reingestion in the degu, an herbivorous Chilean rodent: optimizing digestion through coprophagy. Physiol Biochem Zool 72:78-86

MacArthur RH, Pianka ER (1966) On optimal use of a patchy environment. Am Nat 100:603-609

Mangione AM, Bozinovic F (2003) Ecología nutricional y estrategias de digestión: Compromisos entre obtención de energía y eliminación de toxinas. In: Bozinovic F (ed) Fisiología Ecológica y Evolutiva. Ediciones Universidad Católica de Chile, Santiago de Chile, pp 125-150

Mangione AM, Dearing MD, Karasov WH (2000) Interpopulation differences in tolerance to creosote bush resin in desert woodrats (Neotoma lepida). Ecology 81:2067-2076

Mangione AM, Dearing MD, Karasov WH (2004) Creosote bush (Larrea tridentata) resin increases water demands and reduces energy availability in desert woodrats (Neotoma lepida). J Chem Ecol 30:1409-1429

Márquez J (1999) Las áreas protegidas de la Provincia de San Juan. Multequina 8:1-10

Márquez J, Dalmasso AD (2003) Las comunidades vegetales de los ambientes húmedos del Parque Nacional El Leoncito, San Juan, Argentina. Multequina 12:55-67

Matteucci S, Colma A (1982) Metodología para el estudio de la vegetación. OEA, Monografía 22, Serie Biología

McArthur C, Hagerman AE, Robbins CT (1991) Physiological strategies of mammalian herbivores against plant defenses. In: Palo RT, Robbins CT (eds) Plant defenses against mammalian herbivores. CRC, Boca Raton, pp 103-114

Meyer MN, Karasov WH (1991) Chemical aspects of herbivory in arid and semiarid habitats. In: Palo RT, Robbins CT (eds) Plant defenses against mammalian herbivores. CRC, Boca Raton, pp $167-187$

Ojeda R, Campos CM, Gonnet JM, Borghi CE, Roig VG (1998) The MAB Reserve of Ñacuñán, Argentina: its role in understanding the Monte Desert Biome. J Arid Environ 39:299-313
Owen-Smith N (1993) Evaluating optimal diet models for an African browsing ruminant, the kudu: how constraining are the assumed constraints? Evol Ecol 7:499-524

Poblete AG, Minetti JL (1989) Los mesoclimas de San Juan. Primera y Segunda parte. Informe Técnico 11 del Centro de Investigaciones de San Juan. Univ Nac San Juan 4:31-32

Rapport DJ (1980) Optimal foraging for complementary resources. Am Nat 116:324-346

Redford KH, Eisenberg JF (1992) Mammals of the neotropics: the southern cone. University of Chicago Press, Chicago

Rhoades DF (1977) The antiherbivore chemistry of Larrea. In: Mabry TJ, Hunziker JH, DiFeo DR Jr (eds) Creosote Bush: biology and chemistry of Larrea in New World deserts. Hutchinson and Ross, Stroudsberg, pp 135-175

Robbins CT (1993) Wildlife feeding and nutrition. Academic, San Diego

Robinson BW, Wilson DS (1998) Optimal foraging, specialization, and a solution to Liem's paradox. Am Nat 151:223-35

Salem AZM, Salem MZM, El-Adawy MM, Robinson PH (2006) Nutritive evaluations of some browse tree foliages during the dry season: secondary compounds, feed intake and in vivo digestibility in sheep and goats. Anim Feed Sci Technol 127:251-267

Sánchez-Gonzáles S, Ruiz-Campos G, Contreras-Balderas S (2001) Feeding ecology and habitat of the threespine stickleback, Gasterosteus aculeatus microcephalus, in a remnant population of northwestern Baja California, México. Ecol Freshw Fish 10:191-197

Santos SA, Costa C, da Silva e Souza G, Moraes AS, De Beni Arrigoni M (2002) Qualidade da Dieta Selecionada por Bovinos na Sub-Região da Nhecolândia, Pantanal. Rev Bras Zootecn 31:1663-1673

Sassi PL, Borghi CE, Bozinovic F (2007) Spatial and seasonal plasticity in digestive morphology of cavies (Microcavia australis) inhabiting habitats with different plant qualities. J Mammal $88: 165-172$

Schoener TW (1971) Theory of feeding strategies. Annu Rev Ecol Syst 2:369-404

Sherry TW (1990) When are birds dietarily specialized? Distinguishing ecological from evolutionary approaches. Stud Avian Biol 13:337-352

Shipley LA, Forbey JS, Moore BD (2009) Revisiting the dietary niche: when is a mammalian herbivore a specialist? Integr Comp Biol 49:274-290

Torres-Contreras H, Bozinovic F (1997) Food selection in an herbivorous rodent: balancing nutrition with thermoregulation. Ecology 78:2230-2237 